\title{
Impact of Floods on Livelihoods and Vulnerability of Natural Resource Dependent Communities in Northern Areas of Pakistan
}

\author{
Nusrat Habib ${ }^{1}$, Muhammad Zubair Anwar ${ }^{2}$, Asim Zubair ${ }^{3}$ and Naimatullah Hashmi ${ }^{4}$ \\ ${ }^{1}$ Senior Scientific Officer, National Agricultural Research Centre, Islamabad, Pakistan \\ Email: nusrat.habib@ymail.com \\ ${ }^{2}$ Principal Scientific Officer, National Agricultural Research Centre, Islamabad, Pakistan \\ ${ }^{3}$ M.Phil Scholar, PMAS-Arid Agriculture University Rawalpindi, Pakistan \\ ${ }^{4}$ Professor, PMAS-Arid Agriculture University Rawalpindi, Pakistan
}

\begin{abstract}
Gilgit and Chitral are thought to be most powerless against atmosphere fluctuation including flooding. The recurrence and seriousness of surges in Northern regions in the course of the most recent decade has expanded extensively. Through subjective demonstrating the paper investigates the effect of surges on normal asset subordinate groups in Northern Areas in particular Gilgit and Chitral. The outcomes show that a few attributes of the socio-social condition seem to moderate hazard and diminish defenselessness. In this specific circumstance, the part of informal communities in improving business security is fundamental. The paper reasons that both if there should arise an occurrence of occasional varieties in horticultural yield and surges, people that have successfully expanded their jobs, both occupationally and geologically, are less delicate than people who predominantly accomplish privilege to sustenance by means of product development. In any case, the people getting settlements were likewise in better condition to alleviate the surge related vulnerabilities in the zone.
\end{abstract}

Keywords: Floods; weakness; condition; groups; occupations

\section{Introduction}

The lives of mountain people in the HKH region are affected by climate change (CC). There is increased frequency and duration of extreme climatic events, natural disasters aggravating erosion, land degradation, with consequent decline in soil fertility and crop yields. Furthermore, there is great uncertainty about the rate of change. The capacity of mountain people to deal with these growing stresses is limited with negative impact on poverty.

There is limited empirical evidence on relationships between environmental stressors, adaptation, and human mobility in Pakistan. A study by Mueller et al. (2014) that spans over 
21 years (1991-2012), links individual-level information from the survey to satellite-derived measures of climate variability (Mueller et al. 2014). A study by Gioli et al. (2014) in the bordering region of Gilgit-Baltistan (i.e. Hunza and Yasin valleys), studied the role of migration and remittances in the aftermath of two environmental shocks, the 2010 floods, and the landslide originating the Attabad Lake in upper Hunza, considered as proxies for future climate impacts. This study found a high incidence of male circular labor migration (undertaken by76 percent of the surveyed households), occurring predominantly at the provincial and national scales. The circular labor migration peaked in 2010 - the year in which the two environmental shocks had occurred- with 34 percent of all the migrants' first migration occurring during 2010-2012 over a period spanning from 1985 to 2012. Many of these households had resorted to mobility as a coping mechanism in the aftermath of a shock, rather than as a proactive livelihood diversification strategy. Among those who lost their land (less than 1500 square meter) and those unable to move (due to the lack of financial resources, employable skills, and human capital, family obligations, and illnesses) were significantly poorer (60 percent less income) than the rest of the subsample. This highlights the need for aid agencies and governments to enhance outreach among the most vulnerable segments of society, i.e. those who are unable to 'self-insure' their lives through remittances (Gioli et al 2014). The likelihood that household members would migrate for work is higher among rural communities exposed to rapid onset water hazards (e.g. riverine or flash floods) than those exposed to slow onset water hazards (e.g. drought). The likelihood of labour migration is higher among households located in rural communities affected by very severe drought compared to households in less severely affected rural communities. The assessment of the present and future risk of flooding at sites in northern Pakistan requires an understanding of the climate, which provides the generating mechanisms of floods. Mountain climates are extremely varied and depend on both broad global circulation patterns and local topographic influences (Singh et al, 1995).

This paper evaluates the adapting systems and powerlessness of normal assets subordinate groups in hilly territory of Pakistan amid surges. The study has also covered various issues such as the role of remittances in the reduction of vulnerability of recipient households to floods. 


\section{Methodology}

Present study has been carried out in collaboration with International Centre for Integrated Mountain Development (ICIMOD). This research study adopted household's survey.

\section{A. Study Area}

The study area lies in the Upper Indus Sub-Basin (UISB), where the observed climate trends are anomalous. This case study covers four districts in the UISB: Hunza, Ghizer, Gilgit, and Chitral (see figure 1). Hunza, Gilgit, and Ghizer are located in the region of Gilgit-Baltistan (Eastern Karakoram). Chitral is located in the Khyber-Pakhtunkhwa province (Hindu-Kush).

\section{Figure 1: Map of the study districts in the Upper Indus Basin}

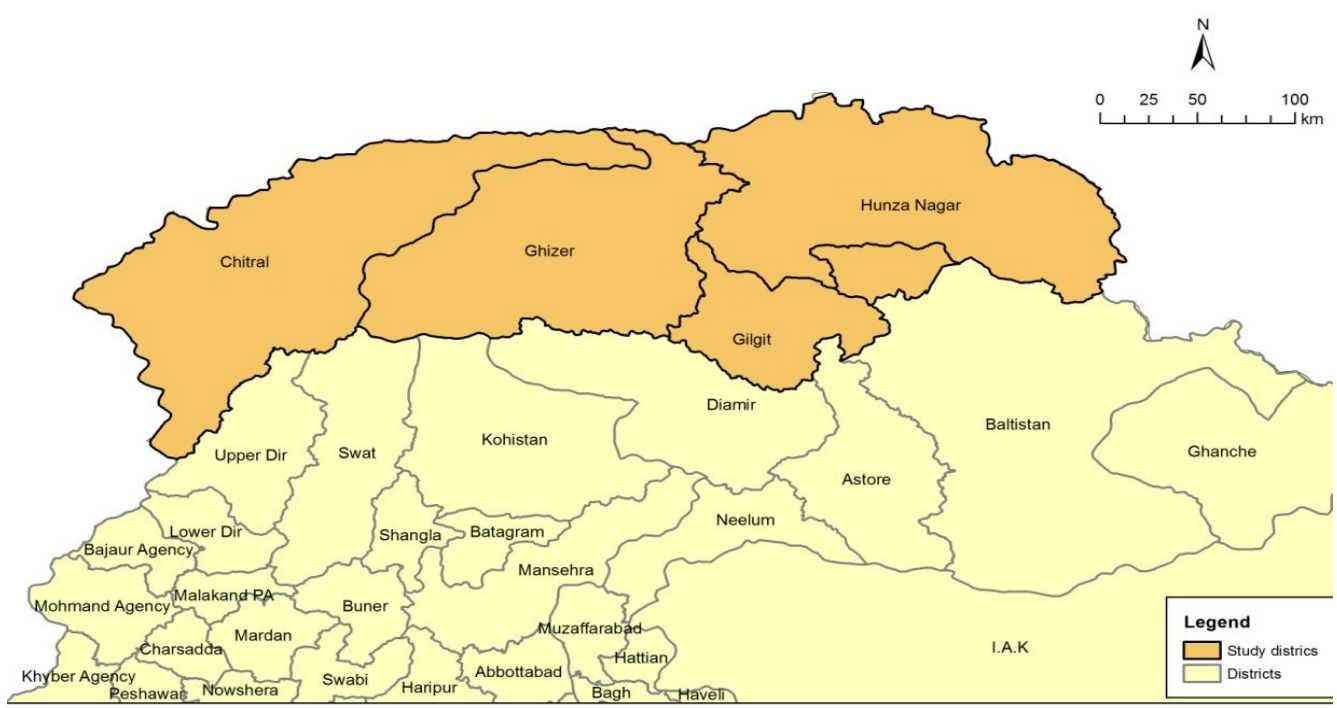

\section{B. Data Collection}

A survey was conducted in Hunza, Ghizer, Gilgit, and Chitral districts from October 2014 to March 2015. These districts were considered as one aggregated area unit, and are representative of the Upper Indus Sub-basin (UISB). The survey gathered primary data on socio-demographic characteristics (age, gender, ethnicity, educational level of the household head), household assets (financial, human, physical, natural, social), prior occurrence and economic damages due to floods between 1984 and 2013, flood response strategies, food and non-food expenditure, livelihood practices. A list of all flood affected villages was prepared for the study area. A sample of 260 was collected from flood affected households while two cases were drop due to insufficient information in the questionnaire. 


\section{Results and Discussions}

The survey was conducted in 2014 from Khyber Pakhtunkhwa (KP) and Gilgit Baltistan (GB) province. A total of 358 flood affected household were surveyed from both provinces that included, 118 households from KP and 240 from GB province. District Chitral was surveyed from KP while District Gilgit, Ghizer and Hunza Nagar were selected from Gilgit Baltistan region with 80 HH's surveyed from each District. Total 18 flood effected villages were surveyed from selected districts, that includes, Damas Pine, Hasis, Kuch Deh, Hakis, Darote,Hoper, Chalt, Minapine, Baltit, Misgar, Bulchi, Jutial, Koghzi, Arundu, Murdan, Nooger, Chnaar and Avi.

\section{A. Household Characteristics}

Among 358 HH's, average age of respondent was 40.5 years while age of HH head was around 52 years. On a total average, $9.11 \mathrm{HH}$ have eaten and slept in one house during the last 6 months. The result showed average number of HH members in different age groups. From 0-5 years of age, 0.72 male and 0.66 females are present in each house. From age group of 6-14, there is around 1 male in every $\mathrm{HH}$ and on average 0.84 female. Similarly, the age group from 15-64 in the surveyed area have around 2.7 male and females on average in each $\mathrm{HH}$ and 0.23 males and 0.17 females on average with more than 65 years of age.

Table 1: Characteristics of flood effected HH's

\begin{tabular}{|l|c|c|}
\hline \multicolumn{1}{|c|}{ Categories } & Mean & $\begin{array}{c}\text { Standard } \\
\text { Deviation }\end{array}$ \\
\hline Respondent's age & 40.59 & 13.744 \\
\hline HH head's age & 52.88 & 14.456 \\
\hline Number of HH member who have eaten and slept for last 6 months & 9.11 & 4.39 \\
\hline 0-5 year male numbers & 0.72 & 1.053 \\
\hline 0-5 year female numbers & 0.66 & 1.025 \\
\hline 6-14 year male numbers & 0.99 & 1.11 \\
\hline 6-14 year female numbers & 0.84 & 1.021 \\
\hline 15-64 year male numbers & 2.79 & 1.608 \\
\hline 15-64 year female numbers & 2.7 & 1.571 \\
\hline older than 65 year male numbers & 0.23 & 0.507 \\
\hline older than 65 year female numbers & 0.17 & 0.381 \\
\hline
\end{tabular}

\section{B. Flood Patterns}

Flood pattern is presented in the table 3, irregular rainfall, intensity of rainfall results in flood and inundation, the response of farmer indicate that flood pattern has been changed 
89.9 percent respondents reported that flood pattern has changed. The frequency of natural disasters has been increasing over the years, resulting in loss of life, damage to property and destruction of the environment. The number of people at risk has been growing each year and the majority is in developing countries with high poverty levels making them more vulnerable to disasters (Living with Risk 2006).

Table 2: Change in flood pattern over last 30years in selected villages

\begin{tabular}{|c|c|c|}
\hline Observation & Frequency & Percent \\
\hline Yes & 322 & 89.9 \\
\hline No & 36 & 10.1 \\
\hline Total & 358 & 100.0 \\
\hline
\end{tabular}

While expanding extreme rain occasions are mindful to the expansion surface spillover. Increments in precipitation, of 5-1\% every decade in the mid/high scopes of the Northern Hemisphere, have likewise been seen since the twentieth century (IPCC, 2001). Results in table 16 indicate that about 57.0 response shows an increase in flood frequency over time the flood are more frequent due to climatic change. Examination of substantial precipitation occasions demonstrates a likelihood of more than $90 \%$ that a $2-4 \%$ expansion in recurrence has happened amid the previous 50 years in the Northern Hemisphere (IPCC, 2001). As indicated by Nott 2006.

Table 3: Change in flood pattern over the last 30 years $(\%)$

\begin{tabular}{|c|c|c|c|c|}
\hline Flood patterns & Increased & No change & Decreased & Total \\
\hline Frequency of flood & 57.0 & 18.4 & 14.5 & 89.9 \\
\hline Area of inundation & 57.5 & 22.1 & 10.3 & 89.9 \\
\hline Duration of inundation & 39.4 & 40.5 & 10.1 & 89.9 \\
\hline Intensity of sand casting & 52.2 & 31.8 & 5.9 & 89.9 \\
\hline Timing of flood & 28.2 & 54.2 & 7.5 & 89.9 \\
\hline Flood damage & 69.6 & 10.9 & 9.5 & 89.9 \\
\hline Frequency of flash floods & 49.4 & 28.8 & 11.7 & 89.9 \\
\hline
\end{tabular}

Note: $10.1 \%$ are missing responses

The most widely recognized reasons for surges are atmosphere related, most outstandingly precipitation. Drawn out precipitation occasions are the most widely recognized reason for flooding around the world. These occasions are normally connected with a few days, weeks or periods of constant precipitation. Human effects on stream catchments impact surge conduct. Likewise the frequency of flood damage and frequency of flash flood also reported high i-e 69.6 and 49.4 respectively. Intensity of sand casting, area of inundation is 
also increased because of devastating losses and lack of adaptation strategies farmer reported that inundation area is increasing every year.

\section{Activities during flood}

Pakistan is one of the most natural disaster prone countries of the World (Ahmad et al, 2004). Flood affects the household economically, socially and physically the table 1 explores the activities adopted by the households during the flood. Surge hazard has a huge danger to numerous groups and, while measures can be taken to decrease the probability and imperative of flooding, the hazard can never be dispensed with out and out (Crossman, et al. 2006).

Table 4: Activities Household did During Flood to Deal with its Immediate Impacts

\begin{tabular}{|c|c|c|c|}
\hline \multirow{2}{*}{$\begin{array}{l}\text { Activities Adopted During } \\
\text { Flood }\end{array}$} & \multicolumn{2}{|c|}{ Household Receiving Remittance? } & \multirow[b]{2}{*}{ Total } \\
\hline & $\begin{array}{l}\text { Receiver of } \\
\text { Remittances }\end{array}$ & $\begin{array}{l}\text { Non Receiver of } \\
\text { Remittances }\end{array}$ & \\
\hline $\begin{array}{l}\text { Move cattle to higher ground- } \\
\text { Practiced to deal during flood }\end{array}$ & $21.8 \%$ & $30.2 \%$ & $52.0 \%$ \\
\hline $\begin{array}{c}\text { Move family to a safer } \\
\text { location- Practiced to deal } \\
\text { during flood }\end{array}$ & $25.7 \%$ & $32.1 \%$ & $57.8 \%$ \\
\hline $\begin{array}{c}\text { Build a raised platform - } \\
\text { Practiced to deal during flood }\end{array}$ & $3.4 \%$ & $3.9 \%$ & $7.3 \%$ \\
\hline $\begin{array}{l}\text { House built on concrete stilts } \\
\text { - Practiced to deal during } \\
\text { flood }\end{array}$ & $2.5 \%$ & $6.1 \%$ & $8.7 \%$ \\
\hline $\begin{array}{l}\text { Relied on less preferred/ less } \\
\text { expensive food- Practiced to } \\
\text { deal during flood }\end{array}$ & $1.1 \%$ & $7.0 \%$ & $8.1 \%$ \\
\hline $\begin{array}{l}\text { Bought food on credit- } \\
\text { Practiced to deal during flood }\end{array}$ & $2.0 \%$ & $4.5 \%$ & $6.4 \%$ \\
\hline $\begin{array}{c}\text { Spent savings on food- } \\
\text { Practiced to deal during flood }\end{array}$ & $4.2 \%$ & $7.3 \%$ & $11.5 \%$ \\
\hline
\end{tabular}

Flood cause damage to livestock crops and human life. Surges every now and again demolish yields and animals, sustenance deficiencies are normal in the outcome (Parker, 2000). Moving cattle to higher grounds and family to safer location were two major activities adopted by the households during the flood. Percentage was $21.8 \%$ and $30.2 \%$ for remittances receiver and non-receiver in case of cattle moving. Ratio was reported high in non-receiver because the raise cattle for livelihood and it's a major asset to cover their emergency needs. Moving the family at safer location was also reported high $32.1 \%$ for non-receiver because 
wealth condition of remittance receivers was high and they have already houses at safer locations. Percentage of other activities like build raised platform 3.9\%, house on concrete stilts $6.1 \%$, Bought food on credit $4.5 \%$ - Spent savings on food- Practiced $7.3 \%$ among the non-receiver . Remittance is a premium source for communities to overcome economic scarcity to withstand, cope and adapt to such changes 2 depending upon their adaptive capacity as well as scale, scope and intensity of economic nuisance (Adger et al., 2002).The ratio of all activities was higher among the non-receiver than remittance receiver because household receiving the remittances have better wealth condition.

Table 5: Who assisted the household to deal with the flood?

\begin{tabular}{|c|c|c|c|}
\hline \multirow[b]{2}{*}{ Assistance } & \multicolumn{2}{|c|}{ Household Receiving Remittance? } & \multirow[b]{2}{*}{ Total } \\
\hline & $\begin{array}{l}\text { Receiver of } \\
\text { Remittances }\end{array}$ & $\begin{array}{l}\text { Non Receiver of } \\
\text { Remittances }\end{array}$ & \\
\hline Family/Relatives- Assisted & $15.4 \%$ & $14.5 \%$ & $29.9 \%$ \\
\hline Friends- Assisted & $13.4 \%$ & $10.9 \%$ & $24.3 \%$ \\
\hline $\begin{array}{l}\text { People of the community- } \\
\text { Assisted }\end{array}$ & $12.6 \%$ & $8.9 \%$ & $21.5 \%$ \\
\hline Insurance company- Assisted & $0.3 \%$ & $0.0 \%$ & $0.3 \%$ \\
\hline Financial institutions- Assisted & $2.2 \%$ & $1.7 \%$ & $3.9 \%$ \\
\hline Local government- Assisted & $2.2 \%$ & $1.7 \%$ & $3.9 \%$ \\
\hline $\begin{array}{c}\text { Provincial government- } \\
\text { Assisted }\end{array}$ & $3.1 \%$ & $5.6 \%$ & $8.7 \%$ \\
\hline National government- Assisted & $1.4 \%$ & $3.4 \%$ & $4.7 \%$ \\
\hline Local NGO- Assisted & $5.9 \%$ & $4.2 \%$ & $10.1 \%$ \\
\hline IO- Assisted Hass assisted & $4.5 \%$ & $7.8 \%$ & $12.3 \%$ \\
\hline $\begin{array}{c}\text { Community organization- } \\
\text { Assisted }\end{array}$ & $3.1 \%$ & $4.7 \%$ & $7.8 \%$ \\
\hline $\begin{array}{c}\text { Women SHG/cooperative- } \\
\text { Assisted }\end{array}$ & $0.3 \%$ & $0.0 \%$ & $0.3 \%$ \\
\hline
\end{tabular}

Catastrophic events get an extraordinary misfortune terms of wellbeing and property. In Pakistan 60 percent to surge 40 percent of the land is presented to quakes, 6 percent to tornados, and some are helpless against dry spell which accounts 25 percent of the land (Gazdar , 1987). Flooding can make harm the populace straightforwardly and by implication for example as far as immediate effect it can make harm arrive, agribusiness, foundation, passings and wounds and as far as in a roundabout way affect it bothers the horticulture generation, water channels and water borne ailments (WHO, 2011). During the flood time period household need assistance and support to rehabilitate, the table 10 explain the sources from where they get the assistance. Family, relatives, friends and fellow community members 
were found major sources of assistance. The ratio of assistance was reported high among the remittance receiver, in case of family friend it was 15.4 percent, friends 13.4 and community 12.6 and household who are non-receiver have low percentage 14.5, 10.9 and 8.9 respectively.

Role of local NGOs was reported high after family and fellow community which was about the 5 percent among the remittance receiver and 4.2 among the non-receiver. Role of government machinery was also reported by some household although their percentage is quite low Provincial and national government assistance was reported by 3.1 and 1.6 among the remittance receiver and 5.6 and 3.4 among the non-receiver. Assistance by the govt. machinery was reported high by the non-receiver of remittance.

\section{Conclusion}

Cultivating is a huge piece of the provincial economy in Chitral and Gilgit even in the fallout of flooding. Be that as it may, progressively vocations are getting to be plainly differing. In any case, the prevalent part of agribusiness in decreasing defenselessness to surges has not moved fundamentally. In connection to the affectability of the jobs, there are substantial contrasts between people in the examination territory. People that have successfully differentiated their vocations, both occupationally and geologically, are substantially less delicate than people who for the most part accomplish privilege to nourishment through product development. The regular and between yearly varieties in sustenance costs can be high, however couple of agriculturists need to buy a substantial piece of their nourishment needs. All things considered, for the most powerless and sustenance unreliable people, the high costs of nourishment in the lean season can unquestionably constitute a colossal powerlessness and a motivator to relocate even notwithstanding the dangers and vulnerabilities related with movement. A few attributes of the socio-social condition in the two groups seem to moderate hazard and lessen weakness through movement from this zone to other huge urban areas of Pakistan, for example, Islamabad, Rawalpindi, Peshawar, Lahore and Karachi and few moved to abroad nations likewise to decrease their powerlessness level which happened because of these surges or some other climatic occasions. 
Pakistan Journal of Humanities and Social Sciences, 5(2), 2017

\section{References}

Adger, W. N., Kelly, P. M., Winkels, A., Huy, L. Q., \& Locke, C. (2002). Mi Gioli et al ration, Remittances, livelihood trajectories, and social resilience. AMBIO: A Journal of the Human Environment, 31(4), 358-366.

Ahmad, S., Hussain, Z., Qureshi, A. S., Majeed, R., \& Saleem, M. (2004). Drought mitigation in Pakistan: current status and options for future strategies, IWMI, 85.

Crossman, M., Richardson, D. and Milne, J.2006. Proceedings of the In Civil Engineers. A Partnership approach to Managing Flood Risk. Civil Engineering. Journal, 159 (2):41-45

Gazdar MN (1987). "Environmental crisis in Pakistan", The Open Press, Kuala Lumpur. Folland, C.K., Miller, C., Bader, D., Crowe, M., Jones, P., Plummer, N., Richman, M., Parker, D.E., Rogers, J. and Scholefield, P., 1999. Workshop on indices and indicators for climate extremes. Asheville, NC, USA, 3-6 June 1997. Breakout group C: Temperature indices for climate extremes, Climatic Change, 42: 31-43.

Gupta, S., Pattillo, C. A., \& Wagh, S. (2009). Effect of remittances on poverty and financial development in sub-Saharan Africa. World Development, 37(1), 104-115

IPCC, (2007) Climate Change Synthesis Report Contribution of Working Groups I, II and III to the Fourth Assessment Report of the Intergovernmental Panel on Climate Change

IPCC, 2001. Climate change. The IPCC 3rd assessment report. The scientific basis, Houghton, J.T., Ding, Y., Griggs, D., Noguet, M., Vander Linden, P., Dai, X., Maskell, K., Johnson, C.A. (Eds). Cambridge: Cambridge, University Press

Nott, J. (2006). Extreme Events: A Physical Reconstruction and Risk Assessment (p. 51). New York: Cambridge University http://dx.doi.org/10.1017/CBO9780511606625.

Parker, J.D. 2000. Floods. Tangler and Francis, National Academy Press, Asian Disaster Preparedness Centre, Thailand

Singh, P., Ramashastric, K.S. and Kumar, N. (1995) Topographic influences on precipitationdistribution in different ranges of the Western Himalayas, Nordic Hydrology, 26, pp 259-284.

WHO (2011): www.who.orghttp://www.wfp.org/countries/pakistan/overview 